\title{
PENERIMAAN IBU - IBU MUSLIM TERHADAP IMUNISASI MEASLES RUBELLA PADA BALITA DI KAMPUNG JAWA WANASARI, KOTA DENPASAR
}

\author{
Ni Luh Putu Indah Swandari*, Made Pasek Kardiwinata \\ Program Studi Sarjana Kesehatan Masyarakat Fakultas Kedokteran Universitas Udayana \\ *)email : 1
}

\begin{abstract}
ABSTRAK
Provinsi Bali berhasil menyelenggarakan kampanye imunisasi Measles Rubella (MR) dengan cakupan diatas target nasional (97,96\%). Meskipun cakupannya melampaui target nasional, sempat terjadi pro dan kontra pada masyarakat muslimnya. Pro dan kontra tersebut terjadi, karena hingga saat ini belum ditemukan vaksin MR yang sifatnya halal. Ibu sebagai orang tua memiliki peran penting dalam penerimaan imunisasi pada anak. Tujuan dari penelitian ini adalah mengetahui penerimaan ibu - ibu muslim terhadap pemberian imunisasi MR (Measles Rubella) pada balita di Kampung Jawa Wanasari, Kota Denpasar. Penelitian ini menggunakaan desain cross sectional deskriptif. Sampelnya adalah ibu - ibu muslim yang memiliki balita di Kampung Jawa Wanasari. Teknik sampling yang digunakan simple random sampling. Ibu yang menerima imunisasi MR pada balitanya sebanyak $77,63 \%$. Ibu sebagian besar merasakan manfaat yang tinggi dari imunisasi MR (81,58\%). Hambatan yang dirasakan dominan rendah $(63,16 \%)$. Ibu menerima dukungan tinggi terkait imunisasi MR dari keluarga $(81,58 \%)$, tenaga kesehatan $(84,21 \%)$ dan tokoh agama $(69,74 \%)$. Penerimaan imunisasi MR di Kampung Jawa Wanasari tergolong rendah dan masih dibawah target nasional.
\end{abstract}

Kata Kunci : Penerimaan, Muslim, Imunisasi

\begin{abstract}
Bali Province has successfully conducted a Measles Rubella (MR) immunization campaign with coverage above national target $(97.96 \%)$. There have been pros and cons of the Muslim community. It was, because of there was no halal MR vaccine from their perspektif. Mothers as parents have a important role in immunization. The purpose of this study was to determine the acceptance of Muslim mothers to vaccinate their under five years old children in Kampung Jawa Wanasari, Denpasar City. This study used a descriptive cross sectional design. Samples in this study were Muslim mothers who had under five years old children. This study used simple random sampling as sampling technique. Mothers who received MR immunization for their children are $77.63 \%$. Mothers mostly feel the high benefits of MR immunization $(81.58 \%)$. The barrier in vaccination were low (63.16\%). Mothers received high support for MR vaccination from family (81.58\%), health workers (84.21\%) and religious leaders (69.74\%). Acceptance of MR immunization in Kampung Jawa Wanasari classified low and under national target.
\end{abstract}

Key Word : Acceptance, Muslim, Immunization

\section{PENDAHULUAN}

Penyakit campak masih menjadi salah satu penyebab kematian anak-anak di Indonesia (Ingridara, 2017). Penularan penyakit campak sangat mudah yakni melalui batuk dan bersin penderitanya (Kemenkes, 2017). Penyakit campak dapat menyebabkan komplikasi serius seperti pneumonia, diare, meningitis bahkan dapat menyebabkan kematian (Kemenkes, 2017).
Rubella atau yang lebih dikenal dengan campak Jerman merupakan salah satu penyakit yang banyak menyerang anak-anak dan dewasa muda (Subrata, 2013). Penyakit rubella hingga saat ini masih menjadi perhatian dalam kesehatan masyarakat, karena berdampak fatal apabila menyerang ibu hamil (Handayani, 2008). Ibu hamil yang terserang rubella pada awal kehamilan berisiko untuk mengalami abortus, kematian janin atau 
janin yang dilahirkan akan cacat seumur hidup (Congenital Rubella Syndrome) (Kemenkes, 2017).

Berdasarkan data laporan PD3I di Provinsi Bali tahun 2017, kasus campak di Provinsi Bali meningkat di tahun 2017. Pada tahun 2016 hanya 25 orang yang terlaporkan. Tahun 2017 sebanyak 179 orang di Provinsi Bali dilaporkan terinfeksi campak (Dinkes Provinsi Bali, 2017). Kasus campak tertinggi ada di Kabupaten Badung yakni sebanyak 71 kasus (Dinkes Provinsi Bali, 2017). Pada tahun 2017 rubella juga merupakan salah satu penyakit yang menyebabkan KLB di Provinsi Bali. Jumlah kasus rubella yang terlaporkan sebanyak 154 kasus (Dinkes Provinsi Bali, 2017).

Global Vaccine Action Plan (GVAP) menargetkan untuk dapat mengeliminasi campak di 5 regional WHO pada tahun 2020 (Pramitasari, 2018). Negara Indonesia juga memiliki komitmen untuk mengeliminasi campak dan pengendalian rubella (Congenital Rubella Syndrome) di tahun 2020 (Kemenkes, 2017). Menurut data surveilans dan cakupan imunisasi campak, imunisasi campak rutin saja belum cukup untuk dapat mewujudkan target eliminasi. Efikasi dari vaksin campak hanya sekitar $85 \%$, sehingga anak yang tidak memiliki kekebalan tubuh terhadap penyakit campak akan menjadi kelompok rentan (Oktaviasari, 2018). Pengendalian rubella di Indonesia dapat dicapai dengan melakukan kampanye imunisasi tambahan. Vaksin rubella disediakan dalam bentuk monovalent maupun kombinasi dengan vaksin lainnya yang menimbulkan serokonversi sebesar
95\% (Kemenkes, 2017). Pemberian 1 dosis vaksin kombinasi antara campak dan rubella (MR) dapat memberikan efikasi sekitar 90\% - 100\% (Kemenkes, 2017). Cakupan imunisasi MR yang harus dicapai agar terbentuk herd immunity adalah minimal 95\%.

Kampanye imunisasi MR dimulai dari tahun 2017 untuk Pulau Jawa dan tahun 2018 untuk diluar Pulau Jawa. Kampanye imunisasi MR fase I dimulai dari bulan Agustus - September 2017. Kampanye imunisasi MR fase I telah berhasil dilakukan dengan mencapai target cakupan nasional sebanyak 100,98\% (Depkes, 2018). Kampanye imunisasi MR fase II di Provinsi Bali dimulai dari bulan Agustus - September 2018. Akan tetapi pada tahap di bulan Agustus - September 2018, Provinsi Bali belum dapat mencapai target nasional (91,52\%). Provinsi Bali kembali memperpanjang kampanye imunisasi MR hingga Oktober 2018. Upaya perpanjangan kampanye imunisasi MR di bulan Oktober ditujukan untuk beberapa kota/kabupaten seperti Badung, Buleleng, Jembrana, Karangasem dan Denpasar yang belum dapat mencapai target nasional. Perpanjangan hingga bulan Oktober 2018 tetap tidak memberikan hasil sesuai yang diharapkan, Kabupaten Buleleng dan Kota Denpasar masih juga belum dapat mencapai target nasional. Cakupan Imunisasi MR saat Kampanye di Provinsi Bali per 31 Oktober 2018 sebesar 95,56\%. Maka dari itu, Indonesian Technical Advisory Group on Immunization (ITAGI) menerbitkan rekomendasi untuk memperpanjang masa 
kampanye imunisasi MR hingga 31 Desember 2018.

Saat penyelenggaraan kampanye imunisasi MR di Indonesia, sempat terjadi pro dan kontra terkait vaksin MR pada masyarakat muslimnya. Pelaksanaan kampanye imuniasi MR menjadi pro dan kontra, karena belum ditemukan vaksin MR yang sifatnya halal dan suci (Fatwa MUI, 2018). Vaksin MR yang di produksi oleh Serum Institute of India (SII) selama proses produksinya memanfaatkan babi sebagai media untuk pertumbuhan virus. Walaupun belum ditemukan vaksin MR yang bersifat halal dan suci, pihak MUI mengeluarkan Fatwa No. 33 tahun 2018 sebagai bentuk dukungan terhadap kampanye imunisasi MR.

Berdasarkan studi pendahuluan yang dilakukan peneliti, pro dan kontra pemberian vaksin MR di komunitas muslim juga sempat terjadi di Kampung Jawa Wanasari, Desa Dauh Puri Kaja Kota Denpasar. Cakupan imunisasi MR saat Kampanye di Desa Dauh Puri Kaja sudah melampaui target nasional (95,69\%). Akan tetapi, cakupan imunisasi MR yang ada di komunitas muslim Kampung Jawa Wanasari belum diketahui. Berdasarkan latar belakang tersebut, perlu dilakukan penelitian untuk mengetahui penerimaan dari ibu - ibu muslim terhadap pemberian imunisasi MR (Measles Rubella) pada balita di Kampung Jawa Wanasari Desa Dauh Puri Kaja, Kota Denpasar.

Tujuan dari penelitian ini adalah mengetahui penerimaan ibu - ibu muslim terhadap pemberian imunisasi $M R$ (Measles Rubella) pada balita di Kampung Jawa Wanasari, Kota Denpasar.

\section{METODE PENELITIAN}

Penelitian ini merupakan penelitian observasional, desain cross sectional deskriptif. Penelitian dilakukan di Kampung Jawa Wanasari Desa Dauh Puri Kaja, Kota Denpasar dalam kurun waktu 5 bulan yakni dari bulan Januari hingga Mei 2019. Sampel pada penelitian ini berjumlah 76 orang yakni ibu beragama islam yang memiliki balita tinggal di Kampung Jawa Wanasari, Kota Denpasar. Kriteria inklusi pada penelitian ini adalah ibu beragama islam yang memiliki balita dan bersedia menjadi responden, sedangkan kriteria ekslusinya adalah ibu yang sedang sakit atau meninggal saat penelitian dilakukan.

Pemilihan sample ditentukan dengan simple random sampling. Unit sampling pada penelitian ini adalah seluruh balita di Kampung Jawa Wanasari. Data nama balita di Kampung Jawa Wanasari diperoleh dari Puskesmas III Denpasar Utara. Data balita tersebut diinput ke dalam aplikasi online Random Number Generator untuk ditentukan siapa yang terpilih menjadi sample pada penelitian ini.

Pengumpulan data pada penelitian ini dilakukan melalui metode wawancara. Metode wawancara dilakukan dengan menggunakan instrumen penelitian berupa kuesioner. Penelitian ini menggunakan analisis data univariat dan cross tabulasi. Pada analisis ini akan diperoleh frekuensi dan persentase dari masing-masing variabel yang akan disajikan dalam bentuk tabel distribusi frekuensi. 


\section{HASIL PENELITIAN}

Tabel 1. Distribusi Frekuensi Penerimaan Imunisasi MR Oleh Ibu Muslim di Kampung Jawa Wanasari

\begin{tabular}{lcc}
\hline Penerimaan & f & \% \\
Imunisasi MR & 17 & 22.37 \\
\hline Menolak & 59 & 77.63 \\
Menerima & 76 & $\mathbf{1 0 0 . 0 0}$ \\
Total & & \\
\hline
\end{tabular}

Berdasarkan tabel 1, dapat diketahui Kaja menerima pemberian imunisasi MR bahwa sebagian besar ibu muslim di untuk balitanya $(77,63 \%)$.

Kampung Jawa Wanasari Desa Dauh Puri

Tabel 2. Distribusi Frekuensi Karakteristik Ibu di Kampung Jawa Wanasari

\begin{tabular}{lcc}
\hline $\begin{array}{l}\text { Karakteristik } \\
\text { Ibu }\end{array}$ & f & \% \\
\hline $\begin{array}{l}\text { Kelompok Usia } \\
\quad<30 \text { th }\end{array}$ & 36 & 47.37 \\
$\quad \geq 30$ th & 40 & 52.63 \\
Pendidikan & & \\
$\quad$ Rendah & 70 & 92.11 \\
$\quad$ Tinggi & 6 & 7.89 \\
Pekerjaan & & 75.00 \\
$\quad$ Tidak bekerja & 57 & 25.00 \\
$\quad$ Bekerja & 19 & \\
\hline
\end{tabular}

Berdasarkan tabel 2, dapat diketahui bahwa ibu - ibu di Kampung Jawa Wanasari Desa Dauh Puri Kaja dominan berada pada kelompok usia $\geq 30$ tahun $(52,63 \%)$. Pendidikan mereka rata - rata pada tingkat rendah $(92,11 \%)$ yakni tamat SD hingga SMA. Ibu - ibu yang sempat menempuh pendidikan tinggi hanya

Tabel 3. Distribusi Frekuensi Persepsi Ibu Terkait Imunisasi MR di Kampung Jawa Wanasari

\begin{tabular}{lcc}
\hline Persepsi Ibu & f & \% \\
\hline Persepsi Manfaat & & \\
Rendah & 14 & 18.42 \\
Tinggi & 62 & 81.58 \\
Persepsi Hambatan & & \\
\hline
\end{tabular}




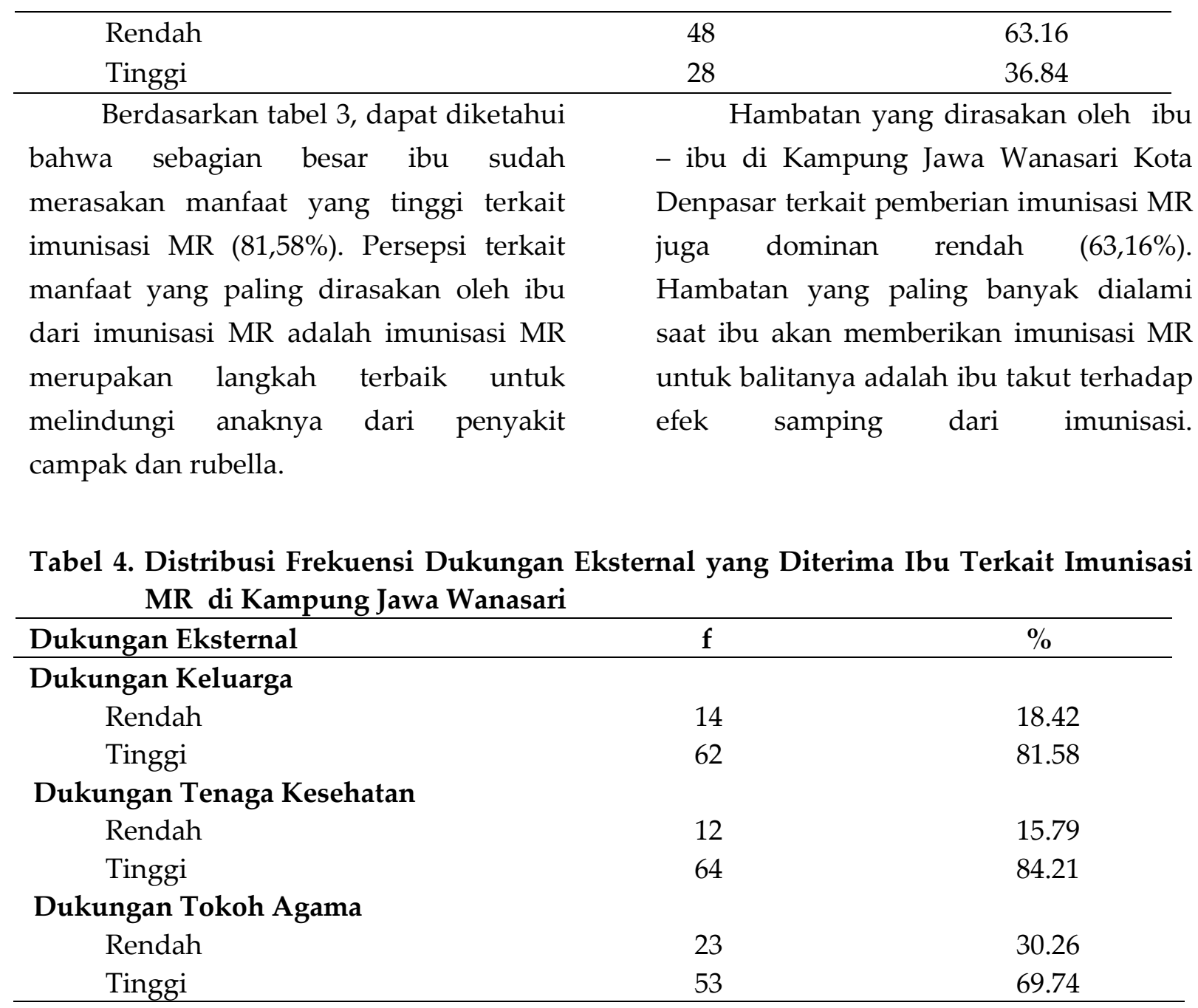

Berdasarkan tabel 4, dukungan dari pihak keluarga yang diterima ibu terkait imunisasi MR tergolong tinggi (81,58\%). Tenaga kesehatan yang ada di lingkungan Kampung Jawa Wanasari Kota Denpasar juga sebagian besar sudah memberi dukungan yang tinggi kepada ibu terkait imunisasi MR (84,21\%). Dukungan dari tokoh agama (Ustadz) yang ada lingkungan Kampung Jawa Wanasari Kota Denpasar mengenai imunisasi MR tergolong cukup tinggi $(69,74 \%)$.

Tabel 5. Distribusi Frekuensi Karaketristik Ibu, Persepsi Ibu dan Dukungan Eksternal Terhadap Penerimaan Imunisasi MR di Kampung Jawa Wanasari

\begin{tabular}{lcccccc}
\hline \multirow{2}{*}{ Variabel } & \multicolumn{6}{c}{ Penerimaan Imunisasi MR } \\
\cline { 2 - 7 } & \multicolumn{2}{c}{ Menolak } & \multicolumn{1}{c}{ Menerima } & \multicolumn{2}{c}{ Total } \\
\cline { 2 - 7 } & $\mathrm{f}$ & $\%$ & $\mathrm{f}$ & $\%$ & $\mathrm{f}$ & $\%$ \\
\hline $\begin{array}{c}\text { Karakteristik Ibu } \\
\quad \text { Kelompok Usia }\end{array} \quad \mathrm{r}$ & & & & & \\
$\quad<30$ tahun & 8 & 22.22 & 28 & 77.78 & 36 & 100.00 \\
$\quad \geq 30$ tahun & 9 & 22.50 & 31 & 77.50 & 40 & 100.00 \\
$\quad \begin{array}{l}\text { Pendidikan } \\
\quad \text { Rendah }\end{array}$ & 17 & 24.29 & 53 & 75.71 & 70 & 100.00
\end{tabular}


Tinggi

Pekerjaan

Tidak bekerja

Bekerja

Persepsi Ibu

Persepsi Manfaat

Rendah

Tinggi

Persepsi Hambatan

Rendah

Tinggi

Dukungan Eksternal

Dukungan Keluarga

Rendah

Tinggi

Dukungan Tenaga Kesehatan

Rendah

Tinggi

Dukungan Tokoh Agama

Rendah
Tinggi

Berdasarkan tabel 5, sebagian besar ibu menerima pemberian imunisasi MR untuk balitanya baik pada ibu kelompok usia $<30$ tahun $(77,78 \%)$ maupun ibu pada kelompok usia $\geq 30$ tahun $(77,50 \%)$. Ibu dengan tingkat pendidikan rendah yang menerima pemberian imunisasi MR untuk balitanya sebesar $75,71 \%$. Ibu dengan tingkat pendidikan tinggi secara keseluruhan $(100 \%)$ menerima pemberian imunisasi MR untuk balitanya. Sebagian besar ibu menerima pemberian imunisasi MR untuk balitanya baik pada ibu yang tidak bekerja $(78,95 \%)$ maupun ibu yang bekerja $(73,68 \%)$.

Ibu dengan persepsi manfaat tinggi cenderung menerima pemberian imunisasi MR untuk balitanya (90,32\%). Ibu dengan persepsi manfaat rendah yang menerima imunisasi MR sebanyak 21,43\%. $\begin{array}{llllll}0 & 0.00 & 6 & 100.00 & 6 & 100.00\end{array}$

$\begin{array}{llllll}11 & 78.57 & 3 & 21.43 & 14 & 100.00\end{array}$

$\begin{array}{llllll}6 & 9.68 & 56 & 90.32 & 62 & 100.00\end{array}$

$\begin{array}{llllll}6 & 12.50 & 42 & 87.50 & 48 & 100.00\end{array}$

$\begin{array}{llllll}11 & 39.29 & 17 & 60.71 & 28 & 100.00\end{array}$

$\begin{array}{llllll}5 & 35.71 & 9 & 64.29 & 14 & 100.00\end{array}$

$\begin{array}{llllll}12 & 19.35 & 50 & 80.65 & 62 & 100.00\end{array}$

$\begin{array}{llllll}4 & 33.33 & 8 & 66.67 & 12 & 100.00\end{array}$

$\begin{array}{llllll}13 & 20.31 & 51 & 79.69 & 64 & 100.00\end{array}$

$\begin{array}{llllll}4 & 17.39 & 19 & 82.61 & 23 & 100.00\end{array}$

$\begin{array}{llllll}13 & 24.53 & 40 & 75.47 & 53 & 100.00\end{array}$

Ibu dengan persepsi hambatan rendah yang menerima pemberian imunisasi MR untuk balitanya sebesar $87,50 \%$. Ibu yang memiliki persepsi hambatan tinggi dan mau menerima pemberian imunisasi MR untuk balitanya sebanyak $60,71 \%$.

Ibu dengan dukungan keluarga tinggi sebagian besar menerima pemberian imunisasi MR untuk balitanya (80,65\%). Ibu yang mendapat dukungan keluarga rendah dan mau menerima pemberian imunisasi MR untuk balitanya sebanyak 64,29\%. Ibu dengan dukungan tenaga kesehatan tinggi cenderung menerima pemberian imunisasi MR untuk balitanya $(79,69 \%)$. Ibu yang mendapat dukungan dari tenaga kesehatan rendah dan mau menerima pemberian imunisasi MR untuk balitanya sebanyak $66,67 \%$. Ibu dengan dukungan tokoh agama tinggi 
yang menerima pemberian imunisasi MR untuk balitanya sebanyak 75,47\%. Ibu yang mendapat dukungan dari tokoh agama rendah dan mau menerima pemberian imunisasi MR untuk balitanya sebanyak $82,61 \%$.

\section{DISKUSI}

$\begin{array}{cll}\text { Kampung } & \text { Jawa } & \text { Wanasari } \\ \text { merupakan salah } & \text { satu daerah yang }\end{array}$ banyak ditinggali oleh masyarakat beragama Islam di Kota Denpasar. Pro dan kontra terkait pemberian vaksin MR juga sempat terjadi disana. Banyak ibu yang masih bingung atau ragu terkait pemberian imunisasi MR. Beberapa ibu ada yang setuju untuk memberikan anaknya imunisasi MR, karena sudah dibolehkan (mubah) oleh tokoh agamanya. Sebagian dari mereka ada juga yang tetap menolak untuk memberikan imunisasi MR, karena ragu akan status kehalalan vaksin. Berdasarkan hasil penelitian, ibu ibu di Kampung Jawa Wanasari yang menerima pemberian imunisasi MR pada balitanya hanya sebesar 77,63\%. Cakupan imunisasi MR di Kampung Jawa Wanasari belum mencapai target nasional, sehingga herd immunity belum bisa terbentuk. Herd immunity secara tidak langsung dapat memberikan dampak (indirect effect) yang sangat besar berupa perlindungan terhadap penyakit pada kelompok masyarakat yang tidak memperoleh imunisasi (Timmreck, 2014). Jika herd immunity belum terbentuk, maka masyarakat di Kampung Jawa Wanasari akan rentan untuk tertular penyakit campak dan rubella.

Sebanyak 22,37\% lainnya ibu di Kampung Jawa Wanasari menolak pemberian imunisasi MR untuk balitanya. Alasan dominan ibu menolak pemberian imunisasi MR adalah karena anaknya sakit saat akan diberi imunisasi. Beberapa dari ibu yang menolak pemberian imunisasi MR, karena meragukan status kehalalan dari vaksin MR. Hasil penelitian ini selaras dengan penelitian dari Sulistiyani dkk (2017), dimana terdapat beberapa ibu yang menolak pemberian imunisasi, karena takut menggunakan bahan haram. Ibu - ibu tersebut memiliki persepsi bahwa Allah tidak akan menciptakan obat dari bahan haram. Terdapat beberapa ibu yang menolak imunisasi MR, karena tidak mendapat izin dari suami dan mertuanya. Hasil penelitian ini sejalan dengan penelitian dari Ritonga (2014), bahwa terdapat beberapa ibu yang tidak memberikan imunisasi pada anaknya, karena dilarang oleh suaminya. Suami dari ibu tersebut melarang pemberian imunisasi dengan alasan anaknya masih terlalu kecil untuk diimunisasi (Ritonga, 2014). Beberapa dari ibu masih ada yang tinggal bersama dengan mertuanya, sehingga keputusan mengenai pemberian imunisasi juga dipengaruhi oleh mertuanya. Beberapa ibu juga lebih memilih untuk menjaga kebersihan lingkungan dan menjaga pola makan anak sebagai langkah untuk mencegah penularan penyakit campak dan rubella. Ibu tersebut percaya bahwa dengan menjauhkan anaknya dari penyedap makanan dapat membuat anaknya tetap sehat walaupun tidak diberi imunisasi.

Penerimaan imunisasi MR yang terdapat pada ibu kelompok usia $<30$ tahun maupun ibu kelompok usia $\geq 30$ 
tahun tidak menunjukkan perbedaan proporsi yang besar. Mereka sebagian besar sama - sama menerima pemberian imunisasi MR untuk balitanya. Ibu pada kelompok usia $<30$ tahun pada umumnya lebih cermat dalam memanfaatkan sosial media, sehingga mereka lebih banyak memperoleh informasi terkait imunisasi MR. Ibu yang banyak terpapar informasi akan pentingnya pemberian imunisasi secara otomatis akan cenderung menerima imunisasi bagi balitanya (Putri, 2016). Ibu pada kelompok usia $\geq 30$ tahun sebagian besar memiliki anak $>1$, sehingga mereka lebih banyak memiliki pengalaman dalam hal pemberian imunisasi pada anaknya.

Ibu di Kampung Jawa Wanasari dengan tingkat pendidikan tinggi secara keseluruhan menerima imunisasi MR. Pada umumnya ibu dengan tingkat pendidikan tinggi (akademik/sarjana) lebih mudah dalam menerima dan mengerti pesan - pesan terkait imunisasi yang disampaikan oleh tenaga kesehatan, baik dalam bentuk penyuluhan maupun media massa (Putri, 2016). Ibu dengan pendidikan rendah juga sebagian besar menerima imunisasi MR pada balitanya. Menurut Siregar dalam Ismet (2013), pengetahuan seseorang tidak hanya dipengaruhi oleh tingkat pendidikan saja. Pengetahuan lebih banyak didapatkan dari pengalaman hidup dan informasi yang diperoleh.

Ibu yang tidak bekerja dan ibu yang bekerja sebagian besar menerima imunisasi MR untuk balitanya. Hasil penelitian tersebut sesuai dengan penjelasan dari Hastono (2009) bahwa aktivitas ibu yang tidak bekerja maupun bekerja, tidak akan menghambat perilaku ibu untuk mengimunisasikan anaknya. Hal tersebut dikarenakan ibu yang bekerja lebih banyak dalam sektor informal seperti pedagang dan jasa. Waktu bekerja dalam sektor informal umumnya relatif fleksibel, sehingga ibu dapat lebih memaksimalkan pemberian imunisasi pada anaknya.

Ibu - ibu di Kampung Jawa Wanasari yang menerima pemberian imunisasi MR untuk balitanya dominan merasakan manfaat yang tinggi dari imunisasi MR. Ibu - ibu tersebut setuju bahwa pemberian imunisasi MR dapat melindungi balitanya dari penyakit campak dan rubella. Selain itu, mereka juga sebagian besar setuju bahwa imunisasi MR merupakan langkah terbaik dalam mencegah penularan virus campak dan rubella. Hasil penelitian tersebut sesuai dengan penjelasan dari Notoadmojo (2007), dimana saat seseorang memulai untuk melakukan perilaku kesehatan, mereka terlebih dahulu akan mempertimbangkan apakah alternatif yang ditawarkan bermanfaat bagi dirinya. Menurut Rosenstock dalam Putri (2016) persepsi manfaat adalah keyakinan terkait keefektifan dari berbagai perilaku kesehatan untuk mengurangi ancaman penyakit atau suatu keuntungan yang dipikirkan individu dalam melakukan perilaku sehat. Penjelasan tersebut selaras dengan penelitian ini dimana ibu dengan persepsi manfaat tinggi cenderung untuk menerima pemberian imunisasi MR bagi balitanya. Pada umumnya ibu yang memiliki persepsi manfaat tinggi akan memiliki pemikiran yang lebih terbuka 
dalam menerima informasi terkait imunisasi MR dari tenaga kesehatan (Putri, 2016). Jumlah ibu dengan persepsi manfaat rendah yang menerima imuniasi MR cenderung sedikit. Ibu yang memiliki persepsi manfaat rendah diakibatkan, karena ibu masih meragukan status kehalalan dari vaksin MR.

Hambatan yang ditemui oleh ibu di Kampung Jawa Wanasari terkait imunisasi MR dominan rendah. Artinya sebagian besar dari ibu - ibu tersebut tidak merasakan hambatan yang berarti saat akan memberikan anaknya imunisasi MR. Menurut Glanz dalam Notoadmojo (2012) persepsi hambatan adalah pandangan mengenai hal - hal negatif yang dapat menyebabkan seseorang ragu untuk berperilaku sehat. Hal negatif tersebut berupa biaya pengobatan yang mahal, pengalaman buruk di masa lalu, dan rasa sakit yang pernah dialami. Persepsi hambatan menurut Rosenstock dalam Putri (2016) adalah suatu kondisi dimana seseorang memiliki keyakinan terhadap hal - hal negatif yang dapat menghambat untuk berperilaku sehat, sehingga mereka akan menunda melakukan upaya - upaya kesehatan. Penjelasan tersebut sesuai dengan hasil penelitian ini, dimana ibu ibu di Kampung Jawa Wanasari yang memiliki persepsi hambatan rendah cenderung untuk menerima pemberian imunisasi MR pada balitanya. Ibu yang merasa tidak memiliki hambatan dalam pemberian imunisasi $\mathrm{MR}$ seperti takut akan efek samping, lebih memilih penggunaan obat - obatan tradisional dan takut karena bertentangan dengan keyakinan/ajaran agamanya akan menerima pemberian imunisasi MR bagi balitanya. Penerimaan imunisasi MR pada ibu dengan persepsi hambatan tinggi cenderung lebih sedikit. Hambatan yang paling banyak ditemui saat ibu akan memberikan imunisasi MR adalah ibu takut terhadap efek samping. Beberapa dari ibu juga lebih setuju bahwa obat obatan tradisional lebih bermanfaat untuk mencegah penyakit campak dan rubella pada balitanya. Hal tersebut sejalan dengan hasil penelitian dari Prabandari dkk (2018), dimana ibu yang menolak imunisasi MR dikarenakan ibu lebih percaya pada penggunaan suplemen herbal dibandingkan dengan vaksin yang mengandung virus.

Dukungan keluarga terhadap imunisasi MR yang diterima ibu - ibu di Kampung Jawa Wanasari dominan tinggi. Pembentukan perilaku kesehatan terutama pemberian imunisasi oleh ibu dapat dipengaruhi oleh orang lain yang dianggap penting seperti keluarga (Ismet, 2013). Menurut Mubarak (2012) keluarga dapat menjadi tempat pengambilan keputusan (decision making) dalam hal kesehatan. Bentuk dukungan yang dapat diberikan oleh keluarga adalah dorongan semangat, pemberian nasehat atau mengawasi tentang pola makan seharihari dan pengobatan (Roria, 2014). Berdasarkan studi yang dilakukan oleh Babirye dkk (2011) keputusan ibu untuk menerima atau menolak pemberian imunisasi dipengaruhi oleh pihak keluarga. Temuan studi tersebut sesuai dengan hasil penelitian ini, dimana ibu ibu di Kampung Jawa Wanasari yang menerima pemberian imunisasi MR untuk balitanya sebagian besar mendapat dukungan yang tinggi dari keluarganya. 
Ibu yang menerima pemberian imunisasi MR sebelumnya terlebih dahulu akan meminta izin kepada suaminya. Ibu yang mendapat izin dari suaminya cenderung akan menerima pemberian imunisasi MR. Tingginya dukungan keluarga terutama suami dapat membentuk suatu kepatuhan dalam diri ibu untuk memberikan imunisasi pada anaknya (Supriatin, 2015). Menurut Rahmawati (2013) ibu yang tidak optimal memperoleh dukungan dari keluarganya, akan sulit untuk bisa mencari pelayanan kesehatan. Penjelasan tersebut justru berbanding terbalik dengan penelitian ini, dimana ibu yang mendapat dukungan rendah dari suaminya juga sebagian besar tetap menerima imunisasi MR untuk balitanya, karena mereka menganggap keselamatan dan kesehatan anaknya lebih penting dari apapun.

Penyelenggaraan kampanye imunisasi MR tidak dapat terlepas dari peran tenaga kesehatan yang berhubungan langsung dengan masyarakat maupun sarana prasarana. Tenaga kesehatan memiliki peranan yang penting terhadap pencapaian cakupan imunisasi. Salah satu tugas tenaga kesehatan adalah memberikan edukasi kepada masyarakat. Menurut Smith (2006) tenaga kesehatan yang baik dapat mempengaruhi orang tua terkait pemberian imunisasi, terutama saat orang tua cemas atau khawatir akan keamanan vaksin. Tenaga kesehatan yang baik dapat membangun kepercayaan yang tinggi dengan orang tua anak. Penjelasan tersebut sesuai dengan penelitian ini, dimana ibu - ibu di Kampung Jawa
Wanasari yang menerima pemberian imunisasi MR untuk balitanya dominan mendapat dukungan tinggi dari tenaga kesehatan di lingkungan tempat tinggalnya. Petugas Puskesmas III Denpasar Utara rutin memberikan edukasi terkait pentingnya pemberian imunisasi MR dan mereka juga tetap mem-follow up agar ibu - ibu di Kampung Jawa Wanasari ingat untuk datang ke pelayanan kesehatan. Penyuluhan terkait imunisasi MR diberikan saat pelaksanaan posyandu di masing - masing RT. Edukasi yang dilakukan oleh tenaga kesehatan merupakan salah satu hal efektif dalam memperbaiki pengetahuan masyarakat terhadap imunisasi (Hafid, 2016). Menurut Dumilah (2016) dukungan secara maksimal yang diberikan oleh tenaga kesehatan dapat menentukan perilaku kesehatan dari ibu. Penjelasan tersebut sesuai dengan hasil penelitian ini, dimana melalui dukungan tenaga kesehatan yang tinggi ibu - ibu di Kampung Jawa Wanasari dominan mau menerima pemberian imunisasi MR untuk balitanya.

Tokoh agama di Kampung Jawa Wanasari sebagian besar sudah memberikan dukungan yang tinggi terkait pemberian imunisasi MR. Tokoh agama merupakan individu yang dinilai memiliki pengaruh sosial kuat di lingkungan masyarakat. Saat ini peran dari tokoh agama tidak hanya sebatas pada spiritual saja, tetapi juga berkembang pada bidang sosial secara umum (Putri, 2016). Tokoh agama dapat menjadi sumber informasi terpercaya dan menjadi panutan dalam menentang atau membenarkan suatu hal yang berkembang di masyarakat (Jelita, 
2017). Menurut Muryadi dalam Jelita dan Arief (2017) penghormatan masyarakat pada tokoh agama (ulama) jauh lebih besar daripada pejabat birokrasi, sehingga tokoh agama mulai dilibatkan dalam program imunisasi untuk membahas status halal dan haramnya unsur dari imunisasi. Walaupun sempat terjadi pro dan kontra di masyarakat muslim, beberapa tokoh agama di Kampung Jawa Wanasari tetap mendukung penyelenggaraan kampanye imunisasi MR sejalan dengan dikeluarkannya Fatwa MUI No.33 tahun 2018. Bentuk dukungan yang dapat diberikan oleh tokoh agama di Kampung Jawa Wanasari adalah dengan memberikan ceramah atau nasehat terkait pentingnya imunisasi MR. Para Ustadz di Kampung Jawa Wanasari memberikan ceramah saat ibu - ibu selesai melaksanakan pengajian. Mereka berusaha semaksimal mungkin untuk mengarahkan dan membimbing agar ibu ibu menerima pemberian imunisasi MR. Mereka memberitahu ibu - ibu bahwa imunisasi pada dasarnya diperbolehkan oleh agama, karena menyangkut masalah kesehatan dan keselamatan manusia. Ibu ibu di Kampung Jawa Wanasari yang menerima pemberian imunisasi MR untuk balitanya sebagian besar ada pada ibu dengan dukungan tokoh agama rendah. Ibu dengan dukungan tokoh agama tinggi justru lebih banyak yang menolak imunisasi MR. Walaupun ibu dominan mendapat dukungan tinggi dari tokoh agamanya mereka tetap ada yang menolak imunisasi MR, karena takut untuk melanggar larangan dari ajaran agamanya. Hal tersebut selaras dengan penelitian dari Putri (2016) dimana, beberapa ibu lebih memilih untuk membiarkan anaknya sakit karena menjauhi barang haram daripada sehat karena menggunakan barang haram yang terkandung di dalam imunisasi. Hasil penelitian tersebut juga sesuai dengan penelitian dari Holt dkk (2009), dimana masyarakat di Pedesaan Afrika dan Amerika mengganggap penyakit sebagai hukuman dari Allah dan orang yang beriman kuat akan dapat mengatasi penyakit yang menyerang dirinya. Adanya persepsi tersebut mengakibatkan masyarakatnya banyak yang menolak imunisasi (Holt, 2009).

\section{SIMPULAN}

Berdasarkan hasil penelitian dapat disimpulkan penerimaan imunisasi MR oleh ibu - ibu muslim di Kampung Jawa Wanasari Kota Denpasar masih tergolong cukup rendah yakni sebanyak 77,63\%. Cakupan imunisasi MR saat kampanye tersebut masih dibawah target nasional.

Ibu - ibu di Kampung Jawa Wanasari Kota Denpasar sebagian besar sudah merasakan manfaat yang tinggi terkait imunisasi MR. Hambatan yang dirasakan terkait imunisasi MR tergolong rendah.

Penerimaan imunisasi MR oleh ibu muslim di Kampung Jawa Wanasari juga dibentuk oleh adanya dukungan tinggi yang diberikan oleh pihak keluarga, tenaga kesehatan dan tokoh agama yang ada di sekitar lingkungan tempat tinggalnya.

\section{SARAN}

Menciptakan koordinasi yang lebih baik lagi dengan tokoh agama mengenai sosialisasi dan penyuluhan terkait 
pentingnya imunisasi, sehingga ibu yang masih memiliki persepsi bahwa pemberian imunisasi MR itu melanggar ajaran Tuhan mau menerima imunisasi MR untuk anaknya. Peneliti selanjutnya

\section{DAFTAR PUSTAKA}

Babirye, J.N. \& Rutemberwa E. (2011). More Support For Mothers : a Qualitative Study on Factors Affecting Immunisation Behaviour In Kampala, Uganda. BMC Public Health $11: 723$.

Dinas Kesehatan Provinsi Bali. (2017). Profil Kesehatan Provinsi Bali 2017. Denpasar.

Depkes. (2018). Imunisasi MR Lindungi Anak dari Kecacatan.

Available:http://www.depkes.go.id Larticle/view/18080200002/imunisas i-mr-lindungi-anak-indonesia-darikecacatan.html (Accessed : 2019, Juni 21)

Dumilah, R. (2016). Hubungan Antara Dukungan Tenaga Kesehatan dengan Status Imunisasi Dasar Pada Bayi Usia 1-2 Tahun di Desa Tanjungpura Kabupaten Karawang. Jurnal Asuhan Kesehatan, $7(2): 32-34$.

Fatwa MUI. (2018). Fatwa MUI No. 33 tahun 2018 tentang Penggunaan Vaksin MR Produk dari SII untuk Imunisasi.

Handayani, S., Bambang H., Gendro W., Susilowati, Subangkit. (2008). Imunitas Terhadap Rubella Pada diharapkan dapat meneliti faktor - faktor lain seperti faktor sosial budaya yang mungkin memiliki hubungan/pengaruh dari penerimaan ibu muslim terhadap pemberian imunisasi MR.

Balita dan Wanita Usia Subur di Kota Surabaya dan Kabupaten Tabanan. Bul. Penelitian Kesehatan, $36(2): 83-90$.

Hafid, W., Santi M., Shrimarti R.D. (2016). Faktor Determinan Status Imunisasi Dasar Legkap Pada Bayi di Puskesmas Konang dan Geger. Jurnal Wiyata 3 (1) : 39 - 44.

Hastono, S. P. (2009). Analisis Data Riskesdas 2007/2008 : Kontribusi Karakteristik Ibu Terhadap Imunisasi Anak di Indonesia. Jurnal Kesehatan Masyarakat Nasional 4 (2) : 91 - 95.

Holt CL, Clark E.M. (2009). Development and Validation of Instruments to Asses Potential Religion-Health Mechanism in an African American Population. Journal of Black Psychology 35 (2) : 271 - 288.

Ingridara, N., Herry G., Budiman. (2017). Hubungan Usia, Status Gizi, dan Status Imunisasi dengan Kejadian Campak pada Anak Usia 0-5 Tahun di Rumah Sakit Umum Daerah Al-Ihsan Periode Januari 2016-Mei 2017. Bandung Meeting on Global Medicine $\mathcal{E}$ Health (BaMGMH), 1 (1) : 50-53. 
Ismet, F. (2013). Analisis Faktor - Faktor yang Berhubungan dengan Imunisasi Dasar Lengkap Pada Balita Di Desa Batuborani Kecamatan Kabilabone Kabupaten Bone Balango. Jurnal FIK Universitas Negeri Gorontalo.

Jelita, N., Arief H. (2017). Pengaruh Sikap dan Persepsi Ibu Terhadap Dukungan Tokoh Agama serta Dukungan Keluarga Terhadap Status Kelengkapan Imunisasi Dasar Bayi. Jurnal Ilmiah Kesehatan Mediahusada 6 (2) : 265 - 274.

Kemenkes. (2017). Petunjuk Teknis Kampanye Imunisasi Measles Rubella (MR). Direktorat Jendral Pencegahan dan Pengendalian Penyakit Kementrian Kesehatan RI.

Mubarak, W. (2012). Pormosi Kesehatan untuk Kebidanan . Jakarta: Salemba Medika.

Notoadmojo, S. (2007). Promosi Kesehatan dan Ilmu Perilaku. Jakarta: Rineka Cipta.

Notoadmodjo, S. (2012). Metodologi Penelitian Kesehatan. Jakarta: Rineka Cipta.

Oktaviasari, K. E. (2018). Hubungan Imunisasi Campak dengan Kejadian Campak di Provinsi Jawa Timur. Jurnal Berkala Epidemiologi, 6 (2) : 166-173.

Prabandari, G. M., Syamsulhuda B.M., Aditya K. (2018). Beberapa Faktor yang Berhubungan dengan Penerimaan Ibu Terhadap Imunisasi Measles Rubella Pada Anak SD Di Desa Gumpang,
Kecamatan Kartasura, Kabupaten Sukoharjo. Jurnal Kesehatan Masyarakat 6 (4) : 573 - 580.

Pramitasari, D. A. I. R. (2018). Hubungan Pengetahuan dan Sikap Ibu dengan Kepatuhan dalam Mengikuti Imunisasi Measles-Rubella (MR) Massal di Posyandu Wilayah Kerja Puskesmas Nganglik II Kabupaten Sleman Yogyakarta. Fikes Unriyo.

Putri, R. S. (2016). Faktor yang Mempengaruhi Kepatuhan Ibu dalam Pemberian Imunisasi Dasar Pada Balita di Dukuh Pilangbangau Desa Sepat Masaran Sragen Tahun 2016. Surabaya: Universitas Airlangga : Skripsi.

Rahmawati, A. (2013). Faktor yang Mempengaruhi Kelengkapan Imunisasi Dasar di Kelurahan Krembangan Utara Kota Surabaya Sebagai Pencegahan Penyakit PD3I. Jurnal Berkala Epidemiologi 2 (2) : 57 - 70.

Ritonga, M. R. S. (2014). Dukungan Keluarga Terhadap Kepatuhan Ibu Melaksanakan Imunisasi Dasar Pada Anak di Desa Tigabolon Kecamatan Sidamanik Kabupaten Simalungun Tahun 2014. Jurnal Sumatera Utara.

Roria, M., Syarifah, Tukiman. (2014). Hubungan Antara Dukungan Keluarga Terhadap Kepatuhan Ibu Melaksanakan Imunisasi Dasar Pada Anak di Desa Tigabolon Kecamatan Sidamanik Kabupaten Simalungun Tahun 2014. 
Smith, K. A. (2006). "Association Between Health Care Providers'Influence on Parents Who Have Concerns About Vaccine Safety and Vaccination Coverage Concerns". American Journal of Pediatrics 5 (118).

Subrata, K., Anak Agung SS, Dewa NW. (2013). Riwayat kontak dan umur sebagai determinan kejadian rubela pada anak di Kabupaten Badung tahun 2012. Public Health and Preventive Medicine Archive, 1 (1).

Sulistiyani, P. Zahroh, Kusyogo. (2017). Gambaran Penolakan Masyarakat Terhadap Imunisasi Dasar Lengkap Bagi Balita. Jurnal Kesehatan Masyarakat (e-Journal) 5 (5) : 1081-1089.

Supriatin, E. (2015). Hubungan Pengetahuan dan Dukungan Keluarga dengan Ketepatan Waktu Pemberian Imunisasi Campak di Pasar Kaliki, Bandung. Jurnal Ilmu Keperawatan III (1) : 1 - 9.

Timmreck, T. C. (2014). Epidemiologi Suatu Pengantar Edisi 2. Jakarta: EGC. 